\title{
THE ISLAMIC TRADITIONAL ARTS AND THE TRACES OF SCIENCE: A STUDY OF ETHNOMATHEMATICS IN AMBE-AMBEKEN DANCE IN ACEH SINGKIL
}

\author{
Nur Ainun Lubis ${ }^{*}$, Dharma Kelana Putra ${ }^{2}$, Amrul Badri ${ }^{3}$, Wahyu Wiji Astuti ${ }^{4}$ \\ ${ }^{1}$ Intitut Agama Islam Negeri Takengon Aceh, Indonesia, e-mail: ainunlubis123@gmail.com, bas.harahap@gmail.com \\ ${ }^{2}$ Balai Pelestarian Nilai Budaya Aceh, Indonesia, e-mail:dharma.kelana@,kemdikbud.go.id, dharmakelana1@gmail.com \\ ${ }^{3}$ Direktorat Jendral Kebudayaan Kemendikbud Aceb Singkil, Aceh, Indonesia, e-mail:amrulpb@gmail.com \\ ${ }^{4}$ Universitas Negeri Medan, North Sumatera, Indonesia, e-mail: wabyu wiji@yahoo.com \\ *Corresponding Authors
}

(C)2021 by the authors. Submitted for possible open access publication under the terms and conditions of the Creative Commons
Attribution-ShareAlike 4.0 International License-(CC-BY-SA) (https://creativecommons.org/licenses/by-sa/4.0/)
do DOI : http:// dx.doi.org/10.30983/it.v5i2.4850
\begin{tabular}{|l|c|c|}
\hline Submission: 30 September 2021 & Revised: 12 December 2021 & Published: 31 December 2021 \\
\hline
\end{tabular}

\begin{abstract}
This research explores the origins of the Ambe-ambeken Dance from Singkil Regency, the form of the Ambe-ambeken Dance, and analyzes the ethnomathematics. As a cultural entity, the Singkil people have a dance known as the Ambe-ambeken or Sakhindayong dance. This study uses a descriptive qualitative method to describe the Ambe-ambeken dance based on historical, anthropological and mathematical approaches. Although the variety of movements looks simple at first glance, this dance is a form of technology of enchantment that is full of wisdom and has an essential role in shaping the community's personality and the spread of Islam in Singkil through the poems that are sung during the dance. Then from a different perspective, it was found that there is a mathematical element that many people do not realize in a traditional dance, namely a geometric transformation. This fact leads to a new assumption that culture in the past was built on spirituality and aesthetic values and by applying mathematical principles in various aspects of life.
\end{abstract}

Keywords: Ambe-ambeken, Traditional dance, Singkil ethnics, Local wisdom, Ethnomathematics.

\begin{abstract}
Abstrak
Penelitian ini mengungkap asal-usul Tari Ambe-ambeken dari Kabupaten Singkil, bentuk Tari Ambeambeken serta menganalisis etnomatematika pada Tari Ambe-ambeken Sebagai sebuab entitas kultural, masyarakat Singkil memiliki sebuah tarian yang dikenal sebagai tari Ambe-ambeken atau Sakbindayong.. Penelitian ini menggunakan metode kualitatif deskriptif, yang bertujuan untuk mendeskripsikan tari ambeambeken berdasarkan pendekatan Sejarah, Antropologi dan Matematika. Meskipun sepintas ragam geraknya terlibat sederhana, tetapi tarian ini merupakan bentuk technology of enchantment yang sarat akan kearifan dan memiliki peranan penting dalam pembentukan kepribadian masyarakat serta penyebaran agama Islam di Singkil melahi syair-syair yang dibawakan selama tarian berlangsung. Kemudian dari sisi yang berbeda, ditemukan bahwa ada unsur matematika yang tidak disadari oleb banyak orang dalam suatu tarian tradisional, yakni berupa transformasi geometri. Fakta ini mengarabkan pada asumsi baru babwa kebudayaan di masa lalu tidak hanya dibangun atas dasar spiritualitas dan nilai estetika semata, tetapi juga dengan menerapkan prinsip matematika dalam berbagai aspek. kehidupan.
\end{abstract}

Kata Kunci: Ambe-ambeken, Tarian tradisional, Suku Singkil, Kearifan lokal, Etnomatematika.

\section{Background}

Aceh Singkil Regency is one of the regions in Aceh Province. This area was formerly part of the South Aceh Regency, later divided in 1999 into a separate administrative area based on Law no. 14 of 1999. This district is directly adjacent to the provinces of North Sumatra and the Indian Ocean and has an area of $187.55 \mathrm{~km}$, divided into
11 sub-districts and 116 villages or gampongs. Aceh Singkil Regency itself is inhabited by two indigenous tribes, such as the Coastal Tribe who inhabited the coastal area to the Banyak Islands, and the Singkil Tribe, who lived around the Upper Singkil River and has now spread to Subulussalam City. 
As an ethnic group, the Singkil people have various traditional arts that are part of their culture. One of them is the Ambe-ambeken dance, also known as the Sakhindayong dance. The Ambe-Ambeken dance is a traditional dance performed by men at certain moments, such as; wedding celebrations, circumcisions, and more. In Singkil language, Ambe-Ambeken can be interpreted by waving. This dance is named that way, because movement variety is dominated by the waving of the dancers' hands. Sometimes this movement also looks like someone rowing a small canoe or bungki, which is used as the main means of transportation by the Singkil Tribe community, especially those who still live in the Singkil watershed. Because the movement is similar to rowing, people in different villages call it the Sakhindayong dance.

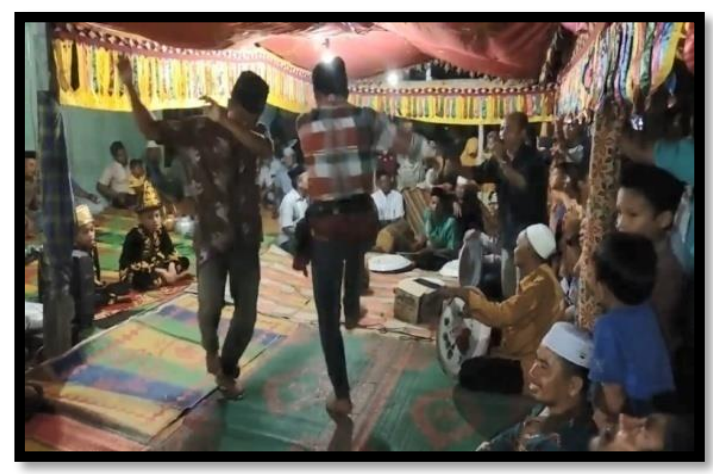

Figure 1. Ambe-Ambeken Dance in Singkil (Source:https://www.youtube.com/watch?v=Zu5pi $\underline{\mathrm{wO} 7 \mathrm{mgs}}$

Traditional dance is not a new thing in research, both in Indonesia and abroad. Vatsyayan $^{1}$ in his book, discusses Indian dance, which is not only a matter of art and tradition but also has an aspect of spirituality in it. Dance as a whole is a technology created to amaze many people (technology of enchantment) ${ }^{2}$. Indirectly, this mentions a little about the element of science in dance. Hanna's ${ }^{3}$ research touched on the issue of gender, which is closely related to dance and the status of a woman's position in society. Traditional dance can be a kind of therapy to treat physical and psychological trauma for certain people, such as victims of sexual violence and others. $^{4}$

The art of dance is usually adapted from people's daily lives, starting from language, speech, and other values. Therefore, contextually, dance tends to change when the social environment requires it to change. Concerning these changes, the art of dance known to the public is divided into three categories based on the background of its creation, like a classical dance based in the Palace, folk dance that developed in rural areas, a contemporary modern dance, which is consumed by people in urban areas with contemporary styles or trends. ${ }^{5}$

The connection between dance and something magical can be seen in that dance integrates technical skills and spiritual abilities. A dancer needs certain rituals to maintain a balance between outward movement and inner strength to create charisma in front of the audience and also to obtain protection from attacks by other dancers who also use magical powers. ${ }^{6}$ Furthermore, it can be seen in the research of Moyo Dance, which uses text analysis and describes its meaning and function from the point of view of the people of South Nias. ${ }^{7}$ In line
${ }^{1}$ Renee Renouf and Kapila Vatsyayan, "Classical Indian Dance in Literature and the Arts", Ethnomusicology, no. 14 (1970): 20, https://doi.org/10.2307/849806.

2 Alfred Gell, "The Anthropology of Time: Cultural Constructions of Temporal Maps and Images," The Anthropology of Time: Cultural Constructions of Temporal Maps and Images, 2021, 1-341, https://doi.org/10.4324/9781003135180.

3 Judith Lynne Hanna, "Classical Indian Dance and Women's Status," Dance, Gender and Culture, 1993, 11935, https://doi.org/10.1007/978-1-349-23842-2_8.
${ }^{4}$ T. D Gilmore, "Gilm African American Sexually Abused Women and the Use of Praise and Worship Dance as a Therapeutic Healing Modality: A Qualitative" , Phenomenologicaore, in T. D,1 Study, 2020.

${ }^{5}$ Mr. Kuswarsantyo, 'Pelajaran Tari : Image dan Kontribusinya terhadap Pembentukan Karakter Anak', Joged 3, no.1 (2013): 17-23

6 Mr. Dr. Hersapandi,SST.,MS., 'Sistem Pewarisan Penari Rol dalam Wayang Orang Panggung', Joged 3, no.1 (2013):24-35

7 Dharma Kelana Putra, "Tari Moyo pada Masyarakat Nias Selatan," Sejarah dan Budaya: Jurnal Sejarah, 
with that, Abdurrahman and Rusliana ${ }^{8}$ explained that the movement in dance has four beauty values, namely wiraga, wirasa, wirama, and wirupa. Wiraga is the physical appreciation (embodiment) carried out by the dancer from beginning to end, while wirasa is the ability of a dancer to feel and appreciate the dance he is playing. Wirama is the flexibility of the body following the rhythm of the music and the patterns of dance movements that he plays, while Harmoni refers to the harmony between the three previous aspects.

Martiara and Wijaya shared the same opinion $^{9}$ that apart from being entertainment, dance represents the cultural identity of an ethnic group. This representation has developed along with changes that occur in society. Meanwhile, there are distinctive patterns in a traditional dance that can be measured scientifically using digital technology, ranging from accompaniment music, range of motion to floor patterns using ethnomathematics as an algorithm ${ }^{10}$. The ethnomathematical approach is also widely used in cultural research, because this concept was born from the application of mathematical concepts in culture that are practiced by humans in their daily lives. ${ }^{11}$

From an understanding of some of the literature above, it is known that traditional dances have local wisdom in them, and research on local wisdom in traditional arts tends to be directed at revealing its meaning and function so that it can be helpful for people's lives in the present and the future.

From the various kinds of literature, it is also known that the Ambe-Ambeken dance has never been studied before. Of course, this is a novelty in cultural studies, especially about the art of traditional dance in the socio-cultural area of the Singkil Tribe. In line with that, this research can be one of the efforts to explore and prove local wisdom by using different analytical methods.

This research assumes that traditional dances were not created just for public entertainment but something more extensive than that. To reveal it, the focus of this research is divided into the following questions: How did the Ambe-ambeken Dance originate in Singkil Regency?; What is the form of the Ambeambeken Dance?; and How is the ethnomathematical analysis of the Ambeambeken Dance?. This description will lead to a different construction and understanding of the art of dance, especially the Ambe-Ambeken Dance as a form of intangible cultural heritage. There is still much knowledge that has not been revealed behind the cultural works handed down by our predecessors, and if we are lucky, knowledge will be revealed before it is lost due to abandonment.

This research was conducted using a qualitative method with a descriptive approach. This study attempts to describe the origins of the Ambe-Ambeken Dance. This paper will show how the Ambe-Ambeken Dance is seen as textual, and how this dance relates to science through an ethnomathematical approach. Data collection was carried out between 19-23 July 2020, in line with the recording of the AmbeAmbeken Dance Cultural Work from Singkil, funded from the DIPA of the Aceh Cultural Values Preservation Center 2020. Data collection was carried out by conducting observations, indepth interviews with informants, and documentation in photos and videos. As for the
Budaya, dan Pengajarannya 14, no. 1 (2020): 116-26, https://doi.org/10.17977/um020v14i12020.

${ }^{8}$ Rusliana I Abdurachman R, Pendidikan Kesenian Tari (Jakarta: PT. Rais Utama, 1979), 35-36

9 Rina Martiara dan Arie Yulia Wijaya, 'Tari Gandrung Terob sebagai Identitas Kultural Masyarakat Using Banyuwangi', Joged 3, no. 1 (2013):49-56
${ }^{10}$ Norsimaa Mustaffa and Muhammad Zaffwan Idris, "Analysing Step Patterns on the Malaysian Folk Dance Zapin Lenga," Journal of Computational and Theoretical Nanoscience 17, no. 2 (2020): 1503-10, https://doi.org/10.1166/jctn.2020.8832.

11 Wahyudin, "Etnomatematika dan Pendidikan Matematika Multikultural," Prosiding Seminar Nasional Pendidikan Matematika Etnomatnesia, 2018, 1-19. 
secondary data obtained by conducting a literature study. Data analysis in this study used descriptive qualitative analysis techniques, which were carried out simultaneously during the data collection process in the field (on going activity analysis). The data obtained were then collected to be processed gradually and systematically, starting from observations, in-depth interviews, and photo and video documentation. Qualitative data are processed in a reduced manner and then presented to facilitate researchers' concluding. The tools used in the process of processing and analyzing data that are mathematical use the Geogebra application.

\section{In Breath with Islam: History and Changes in Ambe-Ambeken Dance}

Historically, the Ambe-Ambeken dance was created by a nobleman from Singkil named Sultan Berdaulat who has the title as Tengku Gemerinting. ${ }^{12}$ This dance was created because Tengku Gemerinting saw the living conditions of the people on the banks of the river far from the crowds, so the idea arose to create public entertainment while still paying attention to Islamic values. Tengku Gemerinting creates dance moves based on what he sees from his surroundings, the goal is to make his movements easier to understand.

The first dance he created was the Alas Dance, whose movements were adapted from the silat martial arts movement from Singkil. After the Alas Dance, Tengku Gemerinting created the Ambe-ambeken Dance adapted from the bungki (sampan) rowing movement, an activity of the Singkil Tribe community since they were teenagers (Interview with Bahauddin, 63).

12 M. Khairunsyah, Abdurahman Adisaputera, and Marice Marice, "The Code Switching of Singkil Language in Indonesian Language Learning Process at Junior High School of Aceh Singkil and Its Usefulness as Student Reading Material', Budapest International Research and Critics in Linguistics and Education (BirLE) Journal 3, no. 4 (2020): 2024-35

13 Z R H Pohan, "Sejarah tanpa Manusia: Historiografi Abad VII-XXI," 2021, https:/ / books.google.com/books?hl=en\&lr=\&id=hzRA EAAAQBAJ\&oi $=$ fnd $\& p g=P A 2 \& d q=$ tradisi + budaya + ja
There is no difference in historical versions of the ambe-ambeken dance, as if there is an understanding in the community which states that the traditional dance of the Singkil Tribe in general, and the ambe-ambeken dance in particular, was created by a Tengku Gemerinting. The only difference lies in the name of the dance between one village and another, which appears due to socio-cultural factors that followed.

Like the traditional villages of the Malay family in the archipelago, the traditional village government system (kuta) in Singkil was also communal with a system of government led by a datuk. Therefore, each village has its sovereignty to regulate and manage the resources in its territory. Then, between one village and another there is no binding political relationship, such as patron-client, superordinate-subordinate, satellite-metropolis, and others. ${ }^{13}$

In the datuk's system of government, each village is connected socially, culturally, and emotionally as part of a great river civilization while maintaining and respecting their respective sovereignty. With this form of bonding, various changes and innovations emerge. We can see in, such as; one village has an innovation that is not owned by another village, then the innovation becomes the hallmark of the village that owns it, or; There are differences in the terms that refer to the same thing, such as the mention of the Mekhambentan Dance and the Menataken Hinei Dance, as well as between the Ambe-ambeken Dance and the Sakhindayong Dance. ${ }^{14}$

At first, this Ambe-ambeken dance could only perform by men. There are strict customary rules to prohibit women from appearing in

$\mathrm{wa}+$ mataraman + dalam + mendukung + ketangguhan + kelua rga\&ots $=\mathrm{UgFY} 4 \mathrm{Od} 6 \mathrm{y} 4 \&$ sig $=$ hRUlCiWfLnUA31Xnne6R SH99WZ0.

14 Khairunsyah, Adisaputera, and Marice, "The Code Switching of Singkil Language in Indonesian Language Learning Process at Junior High School of Aceh Singkil and Its Usefulness as Student Reading Material." Budapest International Research and Critics in Linguistics and Education (BirLE) Journal 3, no. 4 (2020): 2024-35 
public, especially in their capacity as art workers and entertainers. Two things underlie this, among others; (1) Islam teaches that women's beauty is not to be enjoyed by the public, and a violation of this can be a disgrace to the family. Islam has long been a cultural reference in customary law in Singkil, the land of Singkil itself is known as the birthplace of the great scholar Sheikh Abdul Rauf or Shah Kuala; (2) The social situation that occurred in the past was not like it is now, so everyone needs to protect women in their families by preventing them from appearing in public spaces. The goal is not to lose their daughter in a way they do not want or see their daughter forced to marry and live with someone she does not love.

Just like other Acehnese dance characters, the Ambe-ambeken dance is more masculine. In the sense that although it is an art that emphasizes body movements, the movements are not graceful but look stiff and full of energy. When danced in pairs, it shows the gestures of two contesting people and ends with friendship. If drawn from a historical background, in general, dances in Aceh are more intended as a tribal war dance than as a means of entertainment. ${ }^{15}$

In its development, this dance then changed slowly, including modifications to a more subtle range of motion and the involvement of women in dance formations (Interview with Muadz Vohry, 65 years). In this modified version, the variety of movements in the dance becomes smoother and is oriented towards the introduction of two young people who are forming a bond of friendship.

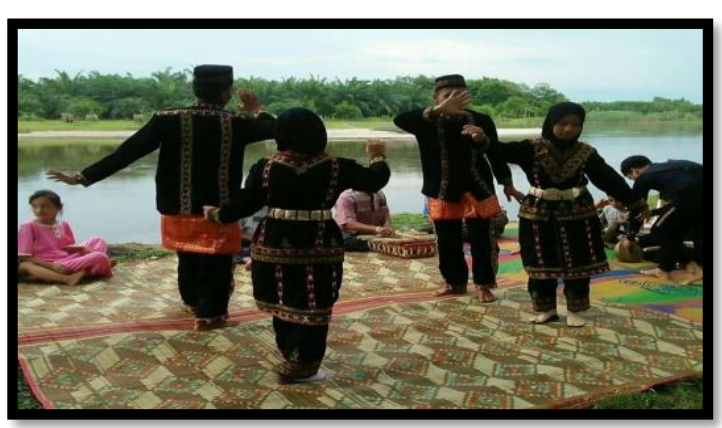

Figure 2. Modified Ambe-ambeken Dance (Source: Primary Data)

Women in Aceh are starting to dare to appear in public spaces because the current government guarantees the rights and obligations of every citizen under the law. Every form of violation of human rights will impact strict legal sanctions so that the risk of losing daughters in ways that their parents do not desire is getting smaller. Primarily because in modern times like this, society in general has lived in a more binding order of universal moral and ethical values. Everyone realizes that the rights of others limit their human rights, so they tend to be able to restrain and control themselves when they are in public.

\section{Get to Know The Form of The Ambe- Ambeken Dance}

The Ambe-ambeken dance is a form of dance that is played in pairs and initially only danced by two men who described the contestation in everyday life. In its development, several dancers play this dance but still in pairs, starting from the number $2,4,6,8$, and so on. According to the number of musical instruments used, dance performances are supported by music players, which usually number around 4-8 people. There is no leader in this dance, because this dance is a representation of the egalitarian values adopted by the Singkil people in the communal government system.

During the dance, a sheikh or Penghulu Khonde will sing poems in Singkil which contain prayers for safety, happiness, health, and other

15 A. B Hermaliza, E., Harvina, Khaira, N., Liyansyah, M., Wibowo, Seudati Aceh, 2014. 
prayers to Allah SWT. The munajat poetry that accompanies this dance is indeed a hallmark of dance in Aceh. The scholars have carried out this tradition in the past as a medium of da'wah ${ }^{16}$. In addition to a series of prayers, the sung poetry also tells the life history of those who have a celebration, messages of advice for married and circumcised, and words of flattery for the guests present.

Slightly different from traditional dances in other areas, the Ambe-ambeken dance does not require luxurious clothing. The dancers usually only wear regular long-sleeved shirts, with dark trousers. For accessories, the dancers usually wear a black cap or skullcap. As for accessories at the waist, the dancers usually use a sarong or lunggi tied in such a way that the end is above the knee. However, in recent years, the sarong has been replaced with a songket or bekilat cloth with a distinctive Singkil motif. Bekilat is used because the variety of patterns and motifs are beautiful and striking, very supportive in dance performances to attract the audience's attention. There is no particular reason for the use of dance clothes like this, it's just that the clothes worn must be polite and represent Islamic values.

As one of the traditional dances, this dance is always played at moments related to people's living habits, such as; circumcision (circumcision of the apostle), marriage. This dance is usually played at night on the second night as part of a series of traditional ceremonies for installing and removing henna. Because the number of dancers is relatively small, this dance is more often played on the front porch of the owner's house. But at certain moments, this dance is also played in public spaces and involves a larger number of dancers.

The floor pattern in the Ambe-ambeken dance forms an imaginary circle, with a diameter of approximately 1 meter. The dancers can move freely by staying in the circle, they face each other and occasionally change places. This floor pattern means that human life is a constant cycle from the past until now, which begins with birth and ends with death.

The dance movements in this imaginary circle describe the dynamics in human life; there is conflict, competition, and cooperation in it. Then, the verses that are sung emphasize that the life that someone lives must be based on goodness so that life becomes more meaningful and valuable for others.

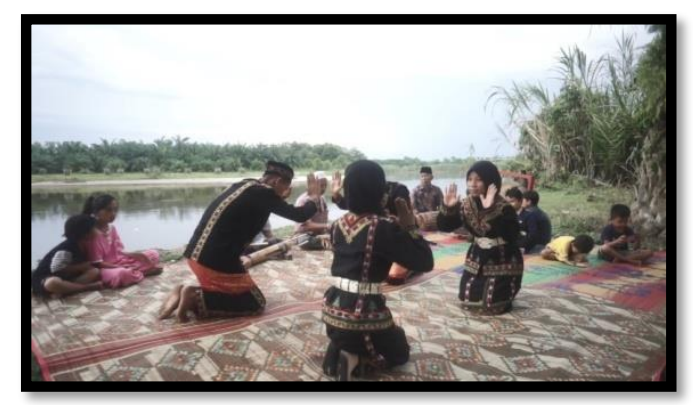

Figure 3. Mekhesalam or closing greetings with mutual respect (Source: Primary Data)

The variety of movements in the Ambeambeken dance consists of five basic movements, plus several additional movements. This dance begins with a respectful greeting or mekhesalam as an opening greeting. This movement is a form of respect for the dancers to the audience. The dancers stand on their knees, the position of the right foot forward and the left knee kneeling, while both palms touch the floor and are pulled to the side and raised in front of the head. This respect is carried out in four directions, starting with the direction of the Penghulu Khonde. If the Penghulu Khonde is in the east, the respect begins towards the east, continues towards the north, south and west. ${ }^{17}$

17 Dharma Kelana Putra, "Laporan Pencatatan Warisan Budaya Tak Benda Asal Aceh Singkil tabun 2020" (Banda Aceh: Balai Pelestarian Nilai Budaya Banda Aceh, 2020), 20 
The next movement is then followed by stomping, clapping, and swinging movements resembling a walking person (mekhambe) for two or four repetitions. After doing several repetitions, the dancers move places while swinging their hands like people rowing a canoe (sakbindayong) for two repetitions. The circular motion (kisar) is an additional movement when the dancers want to move, and usually this movement is also done when the dancer wants to move from one movement to another. And so on until the Penghulu Khonde or sheikh finishes saying the rhyme and gives certain signs so that the dancers slow down the dance and prepare to deliver the closing greetings (mekhesalam) with prayer movements as done at the beginning of the dance.

During the performance, the Ambeambeken dance is usually accompanied by playing traditional musical instruments from the Singkil Tribe, such as; canang wood, canang doal, gong, rapai, and drums sikudidi or also known as drum dua babah. In addition to traditional musical instruments, people also use ketuk or other objects as additional sounds, such as round trays made of iron, drink bottles made of glass, and others. Although not classified as a musical instrument, ketuk provide unique sounds that can add to the lively music that accompanies the dance.

\section{Ethnomathematical Analysis of the Ambe- ambeken Dance}

Traditional dance is basically a type of activity that develops in a particular area, is the result of a process of adaptation and habits passed down from generation to generation. Traditional dance is a cultural product that can be explored from the point of view of mathematics. ${ }^{18}$ Mathematics is a form of culture, which has been integrated into every element of people's lives ${ }^{19}$. Mathematics and culture are something that cannot be avoided in everyday life. It is a source of knowledge and the main needs of each individual, meanwhile culture is a unified whole and a comprehensive guide to behavior in society and plays an important role in growing the noble values of the nation ${ }^{20}$. Meanwhile, ethnomathematical activities are community activities that consciously or unconsciously use mathematical concepts in it.

The ethnomathematical approach is widely used in cultural research because it was born from applying mathematical concepts in culture, which are practiced by humans in their daily lives $^{21}$. Ethnomathematics is a research program related to the history and philosophy of mathematics, with pedagogical purposes, focusing on arts and techniques (tics), explaining, understanding and overcoming (mathema) different socio-cultural environments (ethno) ${ }^{22}$. Many studies on ethnomathematics have been carried out, including numbering on the Tolai Culture in Papua New Guinea ${ }^{23}$, tessellation on
18 Nurus Sa'adah, Arghob Khofya Haqiqi, and Putri Nur Malasari, "Etnomatematika Gerakan Tari Kretek Kudus pada Pembelajaran Matematika," Algoritma Journal of Mathematics Education (AJME) 3, no. 1 (2021): 58-71.

19 Sindi Destrianti, 'Etnomatematika dalam Seni Tari Kejei Sebagai Kebudayaan Rejang Lebong', Jurnal Equation: Teori dan Penelitian Pendidikan Matematika 2, no. 2 (2019): 116

${ }^{20}$ Muchamad Subali Noto, Siska Firmasari, and Mohammad Fatchurrohman, "Etnomatematika pada Sumur Purbakala Desa Kaliwadas Cirebon dan Kaitannya dengan Pembelajaran Matematika di Sekolah Ethnomathematics at the Sumur Purbakala Kaliwadas Village of Cirebon and Relationship with Mathematics
Learning in School," Jurnal Riset Pendidikan Matematika 5, no. 2 (2018): 201-10.

21 Rahmat Wastio Wicaksono, Nur Izzati, and Linda Rosmery Tambunan, "Eksplorasi Etnomatematika Pada Gerakan Pukulan Seni Pencak Silat Kepulauan Riau," Jurnal Kiprah 8, no. 1 (2020): 1-11, https://doi.org/10.31629/kiprah.v8i1.1596.

22 D' Ambrosio, “D’Ambrosio, U. (2001). Ethnomathematics: Link between Traditions and Modernity. Rotterdam, Netherland: Sense Publishers.," Ethnomathematics: Link between Traditions and Modernity., 2001. 23 Paraide, P., Number in the Tolai Culture. Contemporary PNG Studies DWU, Research Journal 9, no. 2 (2008): 77. 
Balinese woven $\mathrm{crafts}^{24}$, Modulo on the Islamic Calendar in Kesepuhan Cirebon ${ }^{25}$, ethnomathematical exploration on the decoration of Batik Trusmi Cirebon ${ }^{26}$, and others. The ethnomathematical analysis of the Ambe-ambeken dance shows that this activity contains elements of mathematics at a simple level. Indirectly, this condition makes the Ambeambeken dance included in the category of ethnomathematical activity.

The ethnomathematical concept that is visible in the Ambe-ambeken dance is found in the pattern of the accompaniment music, but what is most interesting lies in the variety of movements and floor patterns played by the dancers. The ethnomathematics contained in the variety of motion and floor patterns played is a geometric transformation system. Geometry transformation is one of the discussions in geometry regarding changes in shape, location and presentation based on an image and a matrix. ${ }^{27}$ Geometric transformations include; translation, reflection, rotation, and dilation.

\section{Translation}

In simple terms, translation can be interpreted as a shift or displacement, but in principle the intended shift is the movement of objects from one point to another in the geometric plane based on the same distance and direction.
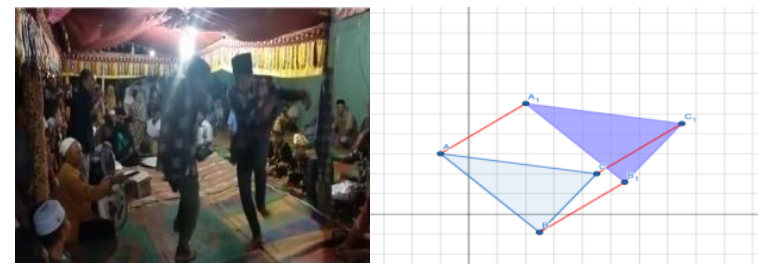

Figure 4. Translation in Ambe-ambeken dance and its geometric transformation

(Source: primary data)
The motion of dancers moving from one point to another can be calculated and measured mathematically using the Transformation Matrix as follows:

$P(x, y) \stackrel{T=\left(\begin{array}{l}a \\ b\end{array}\right)}{\longrightarrow} P^{\prime}\left(x^{\prime}, y^{\prime}\right)=(x+a, y+b)$

$P(x, y) \stackrel{T_{2}{ }^{\circ} T_{1}=\left(\begin{array}{c}a+p \\ b+q\end{array}\right)}{\longrightarrow} P^{\prime \prime}\left(x^{\prime \prime}, y^{\prime \prime}\right)=(x+a+p, y+$
$b+q)$

In the picture above, it can be analyzed that every movement and beat of the dancer's motion with the floor forms an imaginary circle that functions as the axis of the geometric transformation. This transformation is seen when dancers move forward on an axis and then move closer to each other. The back and forth movement of the dancer at a point shows the dancer making a shift but still following the axis.

\section{Reflection}

Reflection is a form of geometric transformation by turning an object from its axis. This transformation moves points by using the reflection property of a plane mirror, where the lines and points change but the object remains the same as it is faced with the mirror. In the Ambe-ambeken dance, indirect reflection appears because the dancers face each other and play the same movement and floor pattern in an imaginary circle space.
${ }^{24}$ Kadek Rahayu Puspadewi and I Gst. Ngurah Nila Putra, "Etnomatematika di Balik Kerajinan Anyaman Bali," Jurnal Matematika 4, no. 2 (2014): 80-89.

${ }^{25}$ Muhammad Alfi Syahrin, T. Turmudi, and Entit Puspita, 'Study Ethnomathematics of Aboge (Alif, Rebo, Wage) Calendar as Determinant of the Great Days of Islam and Traditional Ceremony in Cirebon Kasepuhan Palace', AIP Conference Proceedings, 1708.February (2016)
${ }^{26}$ Arwanto Arwanto, 'Eksplorasi Etnomatematika Batik Trusmi Cirebon Untuk Mengungkap Nilai Filosofi dan Konsep Matematis', Phenomenon: Jurnal Pendidikan MIP A 7, no. 1 (2017):40-49

27 Sugama Maskar and Refiesta Ratu Anderha, "Pembelajaran Transformasi Geometri dengan Pendekatan Motif Kain Tapis Lampung," Mathema Journal Pendidikan Matematika 1, no. 1 (2019): 40-47. 


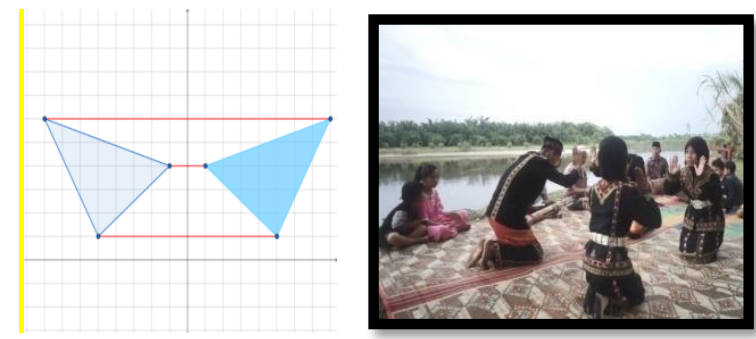

Figure 5. Reflections on the Ambe-ambeken dance and its geometric transformation (Data source: Primary data processing)

In this geometric transformation, one dancer acts as a shadow for the other dancer. Furthermore, there are actually 7 (seven) ways in mathematics that are used to calculate reflection, but only 5 relevant ones are used in the Ambeambeken dance, including:

1. Reflection on the $\mathrm{x}$-axis, where the abscissa is fixed and the ordinate is the inverse. The calculation method can be seen in the following matrix:

$$
\begin{aligned}
\mathrm{A}(\mathrm{a}, \mathrm{b}) \stackrel{\text { sumbux }}{\longrightarrow} \mathrm{A}^{\prime} & =\left(\begin{array}{l}
a^{\prime} \\
b^{\prime}
\end{array}\right)=\left(\begin{array}{cc}
1 & 0 \\
0 & -1
\end{array}\right)\left(\begin{array}{l}
a \\
b
\end{array}\right)= \\
& \left(\begin{array}{c}
a \\
-b
\end{array}\right)
\end{aligned}
$$

2. Reflection on the y-axis, where the abscissa value is the inverse and the ordinate value is fixed. The method of calculation can be seen in the following matrix:

$$
\begin{aligned}
\mathrm{A}(\mathrm{a}, \mathrm{b}) \stackrel{\text { sumbu } y}{\longrightarrow} \mathrm{A}^{\prime} & =\left(\begin{array}{l}
a^{\prime} \\
b^{\prime}
\end{array}\right)=\left(\begin{array}{cc}
-1 & 0 \\
0 & 1
\end{array}\right)\left(\begin{array}{l}
a \\
b
\end{array}\right)= \\
& \left(\begin{array}{c}
-a \\
b
\end{array}\right)
\end{aligned}
$$

3. Reflection of the line $y=x$, which causes the abscissa to be ordinate and the ordinate value to be abscissa. The method of calculation can be seen in the following matrix:

$$
\begin{gathered}
\mathrm{A}(\mathrm{a}, \mathrm{b}) \stackrel{\text { sumbu } y=x}{\longrightarrow} \mathrm{A}^{\prime}=\left(\begin{array}{l}
a^{\prime} \\
b^{\prime}
\end{array}\right)=\left(\begin{array}{ll}
0 & 1 \\
1 & 0
\end{array}\right)\left(\begin{array}{l}
a \\
b
\end{array}\right)= \\
\left(\begin{array}{l}
b \\
a
\end{array}\right)
\end{gathered}
$$

4. The reflection of the line $y=-x$, where the value of the abscissa is the opposite of the ordinate while the ordinate value will be the reciprocal of the abscissa. The method of calculation can be seen in the following matrix:

$$
\begin{gathered}
A(\mathrm{a}, \mathrm{b}) \stackrel{\text { sumbu } y=-x}{\longrightarrow} \mathrm{A}^{\prime}=\left(\begin{array}{l}
a^{\prime} \\
b^{\prime}
\end{array}\right)= \\
\left(\begin{array}{cc}
0 & -1 \\
-1 & 0
\end{array}\right)\left(\begin{array}{l}
a \\
b
\end{array}\right)=\left(\begin{array}{l}
-b \\
-a
\end{array}\right)
\end{gathered}
$$

5. The reflection of the origin $\mathrm{O}(0,0)$, which is a reflection that is at the origin which causes the abscissa and ordinate values to be the opposite. The method of calculation can be seen in the following matrix:

$$
\begin{gathered}
A(\mathrm{a}, \mathrm{b}) \stackrel{\operatorname{titik} O(0,0)}{\longrightarrow} \mathrm{A}^{\prime}=\left(\begin{array}{l}
a^{\prime} \\
b^{\prime}
\end{array}\right)= \\
\left(\begin{array}{cc}
-1 & 0 \\
0 & -1
\end{array}\right)\left(\begin{array}{l}
a \\
b
\end{array}\right)=\left(\begin{array}{l}
-a \\
-b
\end{array}\right)
\end{gathered}
$$

The picture above shows that the reflection can be seen from the movement and position of one dancer who is exactly opposite the other dancer. Then, the dancers show the same movements and hand swings as if to show that the object is dancing in front of a flat mirror.

\section{Rotation}

In simple terms, rotation can be interpreted as rotation. In mathematical studies, rotation is a geometric transformation by rotating all points in a plane about a fixed point: the axis or center of rotation through an angle clockwise or anticlockwise. In the Ambe-ambeken dance, geometric transformations occur in an imaginary circle, becoming the floor pattern in the dance.

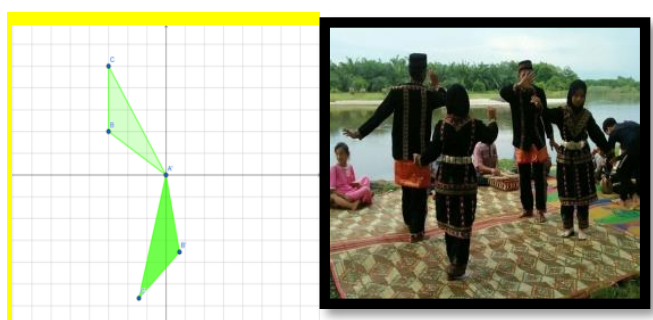

Figure 6. Rotation in the Ambe-ambeken dance and its geometric transformation.

Data source: Primary data processing 
There are six ways to calculate rotation in geographic transformation, but only two are relevant to be applied to the ambe-ambeken dance, called:

1. Rotation with Center $O(0,0)$ of $\propto$, is a rotation by rotating the coordinates counterclockwise by $\propto$ degree. The method of calculation can be seen in the following matrix:

$$
A^{\prime}=\left(\begin{array}{l}
a^{\prime} \\
b^{\prime}
\end{array}\right)=\left(\begin{array}{cc}
\cos \propto & -\sin \propto \\
\sin \propto & \cos \propto
\end{array}\right)\left(\begin{array}{l}
a \\
b
\end{array}\right)
$$

2. Rotation with Center $\mathrm{O}(0,0)$ of $\propto$, then equal to $\beta$, is a rotation by rotating the coordinates point counterclockwise by $\propto$ degree then rotate again by $\beta$ degree. The point of rotation serves not only as an axis, but also as a differentiator. The method of calculation can be seen in the following matrix:

$$
\begin{gathered}
A^{\prime}=\left(\begin{array}{l}
a^{\prime} \\
b^{\prime}
\end{array}\right)= \\
\left(\begin{array}{cc}
\cos (\alpha+\beta) & -\sin (\alpha+\beta) \\
\sin (\alpha+\beta) & \cos (\alpha+\beta)
\end{array}\right)\left(\begin{array}{l}
a \\
b
\end{array}\right)
\end{gathered}
$$

Geometric analysis of the rotation of the image above shows that the dancers change places by rotating clockwise (kisar), a typical floor pattern in the Ambe-ambeken dance. This rotation forms an imaginary circle where the center line on the floor acts as an axis, and this axis becomes a guide for dancers to change places with harmonious movements.

\section{Dilation}

Dilation in mathematics can be interpreted as multiplication, or often also known as a geometric transformation that sees changes in the size of an object, either becoming small or enlarged. Theoretically, the transformation that occurs produces the same image as the shape of the original object, only the size is different. This geometric transformation is very much determined by the center point (axis) and the dilation scale factor, the following is an illustration.

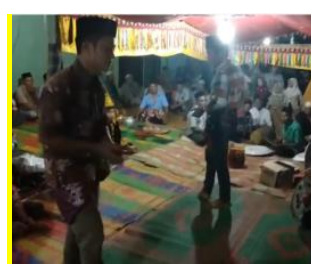

Figure 7. Dilation in the Ambe-ambeken dance and its geometric transformation (Data source: Primary data processing)

In mathematical studies, there are two commonly used ways to calculate dilation, but only one is relevant when applied to the Ambeambeken dance. The transformation matrix that can be used is the dilatation of point $A(a, b)$ to the center of $\mathrm{O}(0,0)$ with a scale factor of $\mathrm{m}$, as described below:

$A^{\prime}=\left(\begin{array}{l}a^{\prime} \\ b^{\prime}\end{array}\right)=\left(\begin{array}{cc}m & 0 \\ 0 & m\end{array}\right)\left(\begin{array}{l}a \\ b\end{array}\right)=\left(\begin{array}{l}a m \\ b m\end{array}\right)$

From the picture above, it can be analyzed that the dilation that occurs in the Ambeambeken dance is not a literal change of form, but rather an optical effect that makes the dancer either bigger or smaller when moving toward or away from the axis, it happen when viewed from a center of point angle. The axis in this case is the midpoint of the imaginary circle that is formed when the dancer plays the floor pattern, which is also the center point and the dilation factor.

\section{Conclusion}

Based on the results of this study, it can be concluded that the Ambe-ambeken Dance in the Singkil community has a unique historical background, where the Sovereign Sultan created this dance with the title Tengku Gemerinting because it is inspired by the daily activities of people living in the riverside area. Textually the form of the Ambe-ambeken dance looks simple at first glance, dominated by hand swing movements resembling people who are rowing and floor patterns that form an imaginary circle. However, behind this simplicity, this dynamic 
dance not only functions as entertainment but also becomes a medium for the spread of Islam and building community character through poetry delivered during the dance. Moreover, currently the ambe-ambeken dance is undergoing a transformation with the addition of a variety of movements, changes in clothing, and the involvement of women as dancers so that this dance is more interesting when performed on various occasions.

So far, perhaps many have thought that traditional dances such as Ambe-ambeken and similar dances are random movements that appear from a happy mood or imitate the movements of people who are rowing. However, the results of the ethnomathematical analysis reveal that this dance has elements of motion with a certain pattern, which forms geometric patterns and can be calculated using formulas, both in the variety of motion and on the floor pattern being played.

The disclosure of the ambe-ambeken dance from the approach of History, Antopology, and Ethnomathematics raises the assumption that people in the past did not solely depend on local wisdom and traditional knowledge based on empirical experience, both in reading natural phenomena and when creating another cultural work. Furthermore, it turns out that they have applied complex mathematical principles in various aspects of life, including in the field of art, without being aware of the generation that continues it today. It is very likely to happen because Algebra itself was born long before the Europeans lived in an advanced civilization until they finally conquered the archipelago several centuries ago.

The emergence of the assumptions above shows that this paper still has many shortcomings, but at the same time these shortcomings become an entry point for conducting further research to reveal how the lives of the previous generations actually lived. From this follow-up research, it is hoped that it will provide a more specific picture of whether local wisdom is created because of repeated experiences, or is actually built on the logic of thinking that is scientific.

\section{References}

Abdurachman R, Rusliana I. Pendidikan Kesenian Tari. Jakarta: PT. Rais Utama, 1979. https://scholar.google.co.id/citations?view _op=view_citation\&hl=id\&user $=1 \mathrm{MQ8}$

Ambrosio, D'. 'D'Ambrosio, U. (2001). Ethnomathematics: Link between Traditions and Modernity. Rotterdam, Netherland: Sense Publishers." Ethnomathematics: Link between Traditions and Modernity., 2001.

Arwanto, Arwanto. "Eksplorasi Etnomatematika Batik Trusmi Cirebon untuk Mengungkap Nilai Filosofi dan Konsep Matematis." Phenomenon: Jurnal Pendidikan MIP A 7, no. 1 (2017): $40-49$. https://doi.org/10.21580/phen.2017.7.1.1 493.

Destrianti, Sindi. "Etnomatematika dalam Seni Tari Kejei Sebagai Kebudayaan Rejang Lebong." Jurnal Equation: Teori dan Penelitian Pendidikan Matematika 2, no. 2 (2019): 116. https://doi.org/10.29300/equation.v2i2.23 16.

Gell, Alfred. "The Anthropology of Time: Cultural Constructions of Temporal Maps and Images." The Anthropology of Time: Cultural Constructions of Temporal Maps and Images, 2021, 1-341. https://doi.org/10.4324/9781003135180.

Gilmore, T. D. "Gilm African American Sexually Abused Women and the Use of Praise and Worship Dance as a Therapeutic Healing Modality: A Qualitative, Phenomenologicaore, T. D,1 Study, 2020.

Hanna, Judith Lynne. "Classical Indian Dance and Women's Status." Dance, Gender and Culture, 1993, 119-35. https://doi.org/10.1007/978-1-349-238422_8.

Hermaliza, E., Harvina, Khaira, N., Liyansyah, M., Wibowo, A. B. Seudati Aceh, 2014. http://repositori.kemdikbud.go.id/12950/. 
Hersapandi. "Sistem Pewarisan Penari Rol dalam Wayang Orang Panggung." Joged 3, no. 1 (2013):

24-35. https://doi.org/10.24821/joged.v3i1.56.

Khairunsyah, M., Abdurahman Adisaputera, and Marice Marice. "The Code Switching of Singkil Language in Indonesian Language Learning Process at Junior High School of Aceh Singkil and Its Usefulness as Student Reading Material." Budapest International Research and Critics in Linguistics and Education (BirLE) Journal 3, no. 4 (2020): 2024-35. https://doi.org/10.33258/birle.v3i4.1434.

Kuswarsantyo, Mr. "Pelajaran Tari : Image dan Kontribusinya terhadap Pembentukan Karakter Anak." Joged 3, no. 1 (2013): 17-23. https://doi.org/10.24821/joged.v3i1.54.

Maskar, Sugama, and Refiesta Ratu Anderha. "Pembelajaran Transformasi Geometri dengan Pendekatan Motif Kain Tapis Lampung." Mathema Journal Pendidikan Matematika 1, no. 1 (2019): 40-47.

Mustaffa, Norsimaa, and Muhammad Zaffwan Idris. "Analysing Step Patterns on the Malaysian Folk Dance Zapin Lenga." Journal of Computational and Theoretical Nanoscience 17, no. 2 (2020): 1503-10. https://doi.org/10.1166/jctn.2020.8832.

Noto, Muchamad Subali, Siska Firmasari, and Mohammad Fatchurrohman. "Etnomatematika Pada Sumur Purbakala Desa Kaliwadas Cirebon dan Kaitannya Dengan Pembelajaran Matematika di Sekolah Ethnomathematics at the Sumur Purbakala Kaliwadas Village of Cirebon and Relationship with Mathematics Learning in School." Jurnal Riset Pendidikan Matematika 5, no. 2 (2018): 201-10.

Paraide, P. "Paraide, P. Number in the Tolai Culture. Contemporary PNG Studies DWU" Research Journal 9, no. 2 (2008): 6977.

Pohan, Z R H. "Sejarah Tanpa Manusia: Historiografi Abad VII-XXI," 2021. https://books.google.com/books?hl=en\&l $\mathrm{r}=\& \mathrm{id}=\mathrm{hzRAEAAAQBAJ \& oi}=$ fnd $\& \mathrm{pg}=\mathrm{P}$ $\mathrm{A} 2 \& \mathrm{dq}=$ tradisi + budaya + jawa + mataraman + dalam + mendukung + ketangguhan + keluar ga\&ots $=\mathrm{UgFY} 4 \mathrm{Od} 6 \mathrm{y} 4 \& \operatorname{sig}=\mathrm{hRU1CiWfLn}$ UA31Xnne6RSH99WZ0.

Puspadewi, Kadek Rahayu, and I Gst. Ngurah Nila Putra. "Etnomatematika di Balik Kerajinan Anyaman Bali." Jurnal Matematika 4, no. 2 (2014): 80-89.

Putra, Dharma Kelana. "Laporan Pencatatan Warisan Budaya Tak Benda Asal Aceh Singkil Tahun 2020,” Banda Aceh: Balai Pelestarian Nilai Budaya Banda Aceh, 2020. https://aceh.tribunnews.com/2021/09/16 /budaya-suku-singkil-diverifikasi-sebelumdidaftarkan-jadi-warisan-budaya-tak-benda.

"Tari Moyo Pada Masyarakat Nias Selatan." Sejarah dan Budaya: Jurnal Sejarah, Budaya, dan Pengajarannya 14, no. 1 (2020): 116-26.

https://doi.org/10.17977/um020v14i1202 0p116.

Renouf, Renee, and Kapila Vatsyayan. Classical Indian Dance in Literature and the Arts. Ethnomusicology. no. 14 (1970):20. https://doi.org/10.2307/849806.

Sa'adah, Nurus, Arghob Khofya Haqiqi, and Putri Nur Malasari. "Etnomatematika Gerakan Tari Kretek Kudus Pada Pembelajaran Matematika." Algoritma Journal of Mathematics Education (AJME) 3, no. 1 (2021): 58-71.

Syahrin, Muhammad Alfi, T. Turmudi, and Entit Puspita. "Study Ethnomathematics of Aboge (Alif, Rebo, Wage) Calendar as Determinant of the Great Days of Islam and Traditional Ceremony in Cirebon Kasepuhan Palace." AIP Conference Proceedings 1708, no. February (2016). https://doi.org/10.1063/1.4941172.

Syai, A., Hermaliza, E., Khaira, N., Fitri, A., \& Zulsapma, T. Bines: Tradisi Berkesenian Masyarakat Dataran Tinggi Gayo. Banda Aceh: Balai Pelestarian Nilai Budaya Banda Aceh, 2012. file:///D:/Buku syai BPBD aCEH.pdf.

Wahyudin. "Etnomatematika dan Pendidikan Matematika Multikultural." Prosiding Seminar Nasional Pendidikan Matematika Etnomatnesia, 2018, 1-19. 
Wicaksono, Rahmat Wastio, Nur Izzati, and Linda Rosmery Tambunan. "Eksplorasi Etnomatematika Pada Gerakan Pukulan Seni Pencak Silat Kepulauan Riau." Jurnal Kiprah 8, no. 1 (2020): 1-11. https://doi.org/10.31629/kiprah.v8i1.1596

Wijaya, Rina Martiara dan Arie Yulia. "Tari Gandrung Terob Sebagai Identitas Kultural Masyarakat Using Banyuwangi." Joged 3, no. 1 (2013): 49-56. https://doi.org/10.24821/joged.v3i1.57.

\section{Interviews}

Bahauddin, (Participant) Interview, \{21 Juli 2020\}.

Muadz Vohry, (Participant) Interview, \{25 Juni $2020\}$.

\section{Website}

Badan Pusat Ststik Kabupaten Aceh Singkil. 2020. Kabupaten Aceh Singkil dalam Angka Tahun 2020. Retrieved from: https://acehsingkilkab.bps.go.id/.

Badan Pemeriksa Keuangan. UU No. 14 Tahun 1999 tentang Pembentukan Kabupaten Daerah Tingkat II Aceh Singkil. retrieved from: https://peraturan.bpk.go.id/Home/Det ails/45300/uu-no-14-tahun-1999.

Manik Channel. 2019. Tari Ambe-ambeken Aceb Singkil saat Acara Khitanan. Retrieved from:

https://www.youtube.com/watch?v=Zu 5piwO7mgs. 